International Journal of Engineering \& Technology, $7(4.34)(2018) 149-152$
International Journal of Engineering \& Technology
SPC
Website: www.sciencepubco.com/index.php/IJET
Research paper

\title{
The Impact of Service Quality, Subjective Norms, and Voluntariness on Acceptance of Provider's Mobile Telecommunication Service in Jordan
}

\author{
Enas Ali Theeb Alnawafleh, Abdul Malek A Tambi*, Abdul Aziz Abdullah, Ghaith Abdulraheem Ali Alsheikh, \\ Puspa Liza Ghazali \\ Faculty of Economics and Management Sciences, Universiti Sultan Zainal Abidin, Gong Badak Campus, 21300 Kuala Nerus, Terengga- \\ nu, Malaysia \\ *Corresponding author E-mail: malekahmad@unisza.edu.my
}

\begin{abstract}
Technology has made life easier in today's world. In addition, developments in technologies and communication have become commonplace for majority of people. Global telecommunication development has reduced distances around the globe, and made it easy for businesses to proliferate worldwide. This study explored the factors affecting the use of telecommunication services among customers through mobile phones. The Technology Acceptance Model (TAM) has been extensively used in the field of technology use but is lacking when it comes to factors that affect customers' intention to use service as they focus more on technology. On the basis of review findings, there is a positive relationship between service quality, subjective norms, perceived usefulness and perceived ease of use of service and voluntariness moderates the relationship between subjective norms and intention to use service. These and other relationships are considered in the development of a Service Acceptance Model.
\end{abstract}

Keywords: Technology; Service; Quality; Behavior; Intention; Telecommunication.

\section{Introduction}

The fast-changing world and business competition that constantly increased and changed had urged telecommunication firms to exert efforts for the renewal of their processes and services [1]. Jordan's mobile telecommunication industry was rife with increased competition and growth, with upgrades and extension being continuously conducted. In fact, in the Middle East, the industry was the top industry in terms of competition and this was why the Jordanian government was workin9g on the mobilization of the most expansive communication service assess at reasonable costs in the form of the Middle East North Africa Financial Network (MENAFN) and was working on guaranteeing that the telecommunication sector had healthy competition. In so doing, the private sector was welcomed to participate and invest in the sector's development [2]. Despite the expanding studies in literature, empirical evidence remained minimal on the valuable service elements [3-5]. As a result, the underlying reasons behind the consumers' adoption and intention towards adopting services remained ambiguous [6]. Because of the ongoing competition in the telecommunication sector, organizations were largely concentrating on innovation as it was deemed to be the fundamental driver behind the growth of the economy.

\section{Literature Review}

A description on the mobile telecommunication service market in Jordan, service quality and behavioral intention concepts, and influencers of service use are given in sections 2.1 to 2.4 respectively.

\subsection{The Mobile Telecommunication Service Market in Jordan}

The Jordanian government was taking considerable steps to privatize economic sectors [7] and introduced a policy directed towards upgrading and developing the telecommunication infrastructure and services within the nation. The continuous liberalization of the ICT sector in Jordan was the driver behind the growth of the telecommunication market to a level that was in excess of a billion dollars yearly [2]. Several steps had been adopted to liberalize the market in Jordan to introduce fair competition; in fact, Jordan was ripe for investments, providing opportunities for new investments as well as new innovative services. However, Jordan experienced a slow process of implementing new technologies. For example, despite its rapid growth worldwide, mobile learning was still considered as a new technology [8].

\subsection{Service Quality}

In the industry of service provision, service is a distinct type of product that is characterized by its intangibility [9]. In a narrower view, quality, as an element had been viewed as a minimum strategic element to achieve competitive advantage and improve services and products in organizations $[10,11]$. Service quality is defined as the gap between customers' expectations concerning products/services and awareness, and their feelings following the use of the products/services [12]. In other words, service quality reflects the difference between the expected quality prior to the 
process of purchase and the actual quality experienced by the consumer post-purchase [13].

The importance of service quality had been highlighted in the Nigerian telecommunication sector, where the mobile market was one of the fastest growing sectors. That had expedited the commercial and industrial sector growth, and contributed to the development of the nation's economy. The growth rate of telecommunication facilities use had increased in manifold, specifically when it came to the number of subscribers to the service [14]. In [15] had proved that customers' perceived service quality and its corresponding dimensions influenced their behavioral intentions.

\subsection{Behavioral Intention}

Behavioral intention was described by [16] as an individual's intention to perform a specific behavior. It was regarded as the main predictor of actual behavior, within a situation of voluntary performance of the action. In that regard, intention was considered to encompass the motivational factors that affected behavior, which indicated the way people were inclined to try, and the level of their efforts in behavioral engagement $[17,18]$.

The level of intention was determined by the subjective probability that the individual would conduct the behavior, and it was gauged by placing the subject along a subjective-probability dimension, involving a relationship between the subject and certain behaviors [19]. Prior studies in the literature evidenced the role of behavioral intention in determining individual use of mobile services and future system [17, 18, 20-22]. Some of those studies evidenced that subjective norms influenced the individual's attitude, which in turn influenced his or her intention towards adopting specific behavior forms.

In the business world, intention towards service use is related to the provision of service that is of standardized quality. Several studies have been conducted to examining service quality along with several theories and models proposed to tackle service quality issue based on its various dimensions. Service quality definitions and measures had been proposed in the literature although a single universal definition of the concept had yet to be proposed [23].

\subsection{The Influencers of Technology Service Use}

Generally speaking, technology service use is influenced by several factors, among which subjective norm is one of them. Subjective norm was described as an individual's perception that the majority of people important to that person think that he or she should do or refrain from doing a specific behavior [24]. Adding to that, subjective norm is the social component, related to behavior, as perceived by referent individuals (friends, university instructors, and peers) [25]. In other words, the actions of an individual are determined by those that are important to him or her [26] in the form of perceived social pressure to carry out a certain behavior [27]. Similarly, in [28] described subjective norms as views from people who are important to the individual pertaining to whether or not he or she should perform behaviors along with his or her tendency towards doing or refraining from doing such behaviors [29]. According to [30], subjective social norms are the beliefs of a person on how and what people important to the person think he or she should do (do or refrain from doing a certain behavior).

Generally speaking, TAM has two major components that predicts intention towards technology adoption namely perceived ease of use and perceived usefulness [31]. Their influence is compounded with by users' perceived value of the technology [32]. In the realm of use or non-use of service provided by the technology, the service's perceived usefulness and perceived ease of use were of most importance as evidenced by the fact that they were, in the Technology Acceptance Model (TAM), noted to be the most examined variables when it came to new innovation use [33].

One research had suggested that sad and fear were two instantaneous emotions that had negative moderating effect on perceived usefulness and behavioral intention to use computer-based assessment systems [34]. In the context of telecommunication, in [35] reported it was important for manufacturers of mobile telecommunication technology to maintain and increase the usefulness of mobile sets. In mobile commerce, however, the determinants of mobile service adoption and intention towards adoption were still ambiguous in terms of their basic value-added components as explained by considerable number of authors [36].

As for their conceptualizations, perceived ease of use referred to the perception of individuals using a specific system free of effort while perceived usefulness referred to the level to which an individual believed that his or her job will be enhanced by using the system, in light of performance and productivity, the two determinants of consumer confirmation and use of system [36]. The ease of use construct, was found to have a positive and significant effect on perceived usefulness and attitude [37, 38], That was evident in some consumer studies that found that the relationship between perceived usefulness and behavioral intention to be more significant [29, 40, 41]. In one study on m-commerce usage, in [42] had reported a direct and significant relationship between perceived usefulness and intention to use service.

In the context of learning environment, voluntariness may play a greater direct role as learners do not often have a choice when adopting technology for learning. In [43] showed that voluntary trial of mobile learning might lead to facilitation from others, particularly those with higher academic positions. Contrastingly, voluntariness was found not to have any significant effects on user's intention [44] and it indirectly influenced behavioral intention [43].

\section{Theory Development}

This paper describes the relationship between service quality, subjective norms, perceived ease of use, perceived usefulness, voluntariness, and intention to use service. Theory of TAM, TPB, UTAUT and SERVQUAL models are central to this study as it is widely used by the authors to interpret and explain the intention to use service.

\subsection{Technology Acceptance Model}

The technology acceptance model was introduced by [20] is an extension of the Theory of Reasoned Action to explain the acceptance and usage of Information Technology (IT). The TAM has become a popular model owing to its extensive reference in the literature when it comes to acceptance of technology. It posits that behavioral intention to use determines technology acceptance as well as its actual use, and the construct is affected by use attitudes, perceived ease of use, and perceived usefulness of technology (direct and indirect effects). Perceived ease of use and perceived usefulness influenced attitude towards IT use [45]. In [46] believed that TAM was still less than complete where other variables have to be included to TAM to strengthen its predictability.

\subsection{Theory of Planned Behavior}

The theory of reasoned action proposed by [16], with its extension, the theory of planned behavior by [47] have been used in literature in different contexts. The major aim behind the TPB was to predict and shed light on the individual's behavior, and to explain behavior based on the intention of the individual. That was because intention was formed by attitude toward behavior, social norms, and perceived behavioral control [7]. The TPB had been extensively utilized in various cases, including holiday selection [48], influence of word-of-mouth on restaurant selection [49], and tourists' attitudes towards traveling [50]. Studies had shown that TPB was capable of explaining and predicting individual behavior 


\subsection{Unified Theory of Acceptance and Use of Technolo- gy}

in [51-52] had proposed the unified theory of acceptance and use of technology (UTAUT) after the review of eight popular models/theories namely TRA, TAM, Motivational Model (MM), TPB Combined TAM, and TPB (C-TAMTPB), Model of PC Utilization (MPCU), Innovation Diffusion Theory (IDT), and the Social Cognitive Theory (SCT). The UTAUT provides moderating constructs that moderate the influence of the four major constructs on both intentions to use and behavior, including voluntariness of use.

\subsection{SERVQUAL Model}

The SERVQUAL model was developed and proposed by [12] for the measurement of service quality using five dimensions namely reliability, responsiveness, assurance, empathy, and tangibles. The above dimensions were initially gauged by using the disconfirmation method involving quality measurement by subtracting expectation scores from perception scores, and computing the scores to achieve the relative importance of every aspect of service quality. The outcome obtained from a one-off study achieved a measure that relayed whether or not the expectations of customers were exceeded [12].

The originally proposed instrument had been revised and used in different service settings, including the banking sector [53], the telecommunication sector [2,54], as well as the hotel sector [55]. The SERVQUAL results are useful to identify whether or not service components are good or bad, and performance is comparable to competitors or different branches of the same company. In [54] had demonstrated that the instrument was capable of measuring customer satisfaction in a selected service industry. While several studies dedicated to intention to use had suggested the need to investigate the effect of subjective norms on intention to use [29], there were studies that laid emphasis on extending TAM to include other variables such as service quality $[56,57]$.

\section{Service Acceptance Model (SAM)}

In [19] had made great contributions in the field of social psychology in light of technology acceptance, where actual service depended on the intention toward behavioral performance. The TPB and UTAUT set the stage for developing the service acceptance model where voluntariness and subjective norms are hypothesized to be the determinants of behavioral intention, the positive or negative feeling of an individual. Voluntariness comprises a set of accessible behavioral beliefs that connect services to different after effects and attributes as depicted in Fig. 1.

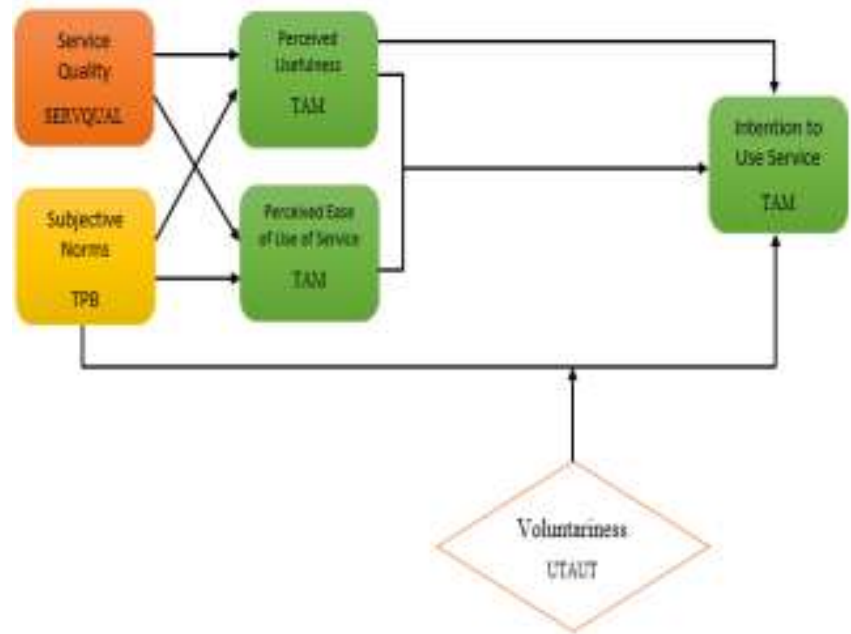

Fig. 1: Service Acceptance Model

\section{Conclusion}

In this paper, the researchers primarily attempt to examine the influence of service quality and subjective norms on intention to use service and postulate the mediating effect of perceived ease of use and perceived usefulness of service. In addition, voluntariness is supposedly designated as the moderator of the influence of subjective norms on behavioral intention on the basis of relevant studies and in the context of the telecommunication sector. Successful organizations are made to be so by their customers and in relation to this, service quality is among the top investments of an organization owing to its role in enhancing customer knowledge, attitudes, and behavior. Specifically, intention towards service use is one of the most significant work-related attitude where a customer having a high level of intention to use service is a guaranteed organizational asset. The present study proposes a conceptual framework derived from TAM, TPB, UTAUT and SERVQUAL models.

\section{Acknowledgement}

The authors would like to thank the Research Management, Innovation and Commercialization Centre, Universiti Sultan Zainal Abidin, Terengganu, Malaysia for providing the financial assistance to support the publication of this article.

\section{References}

[1] Hajir JA, Obeidat B, Al-dalahmeh M \& Masa'deh R (2015), The role of knowledge management infrastructure in enhancing innovation at mobile telecommunication companies in Jordan. European Journal of Social Sciences 50(3), 313-330.

[2] Alnsour M, Abu Tayeh B, \& Awwad Alzyadat M (2014), Using SERVQUAL to assess the quality of service provided by Jordanian telecommunications sector. International Journal of Commerce and Management 24(3), 209-218.

[3] Al-Hubaishi HS, Ahmad SZ \& Hussain M (2017), Exploring mobile government from the service quality perspective. Journal of Enterprise Information Management 30(1), 4-16.

[4] Olatokun WM \& Ojo FO (2016), Influence of service quality on consumers' satisfaction with mobile telecommunication services in Nigeria. Information Development 32(3), 398-408.

[5] Sung M, Cho S-H, Kim KS, Kwon HK,. Kang B-S, Oh DS, Lyu DS, Lee H, Kim SM,. Lee JH \& Chung HS (2017), Demonstration of IFoF based $5 \mathrm{G}$ mobile fronthaul in $28 \mathrm{GHz}$ millimeter wave testbed supporting Giga-bit mobile services. Proceedings of the IEEE Optical Fiber Communication Conference, pp. 1-12.

[6] Heo J-Y, Lim CH \& Kim KJ (2017), Scales for measuring mobile service quality: A literature review and identification of key dimensions. International Journal of Services and Operations Management 27(4), 524-548.

[7] Cunningham K (2002), Factors influencing Jordan's information revolution: Implications for democracy. Middle East Journal 56(2), 240-256.

[8] Khan AI, Al-Shihi H, Al-Khanjari ZA, \& Sarrab M (2015), Mobile Learning (M-Learning) adoption in the Middle East: Lessons learned from the educationally advanced countries. Telematics and Informatics 32(4), 909-920.

[9] Hai PT, Le Duc Toan VVT \& Thuong MT (2017), Factors affecting customer satisfaction with the quality of services: Empirical evidence at Da Nang international airport, Vietnam. Asian Journal of Empirical Research 7(3), 61-74.

[10] Li L, Su Q \& Chen X (2011), Ensuring supply chain quality performance through applying the SCOR model. International Journal of Production Research 49(1), 33-57.

[11] Qutaishat FT, Khattab SA, Zaid MKSA \& Al-Manasra EA (2012), The effect of ERP successful implementation on employees' productivity, service quality and innovation: An empirical study in telecommunication sector in Jordan. International Journal of Business and Management 7(19), 45-54.

[12] Parasuraman A, Zeithaml VA \& Berry LL (1988), SERVQUAL: A multiple-item scale for measuring consumer perceptions of service quality. Journal of Retailing 64(1), 12-40. 
[13] Joudeh JMM (2017), The impact of service quality dimensions upon customers' satisfaction: An empirical study applied in the Jordanian mobile telecommunication sector. International Review of Management and Business Research 6(1), 184-198.

[14] Ojo O (2010), The relationship between service quality and customer satisfaction in the telecommunication industry: Evidence from Nigeria. BRAND. Broad Research in Accounting, Negotiation, and Distribution 1(1), 88-100.

[15] Twaissi N \& Al-Kilani M (2015), The impact of perceived service quality on students' intentions in higher education in a Jordanian governmental university. International Business Research 8(5), 8192.

[16] Ajzen I \& Fishbein M (1980), Understanding attitudes and predicting social behaviour. Prentice Hall.

[17] Ajzen I (1991), The theory of planned behavior. Organizational Behavior and Human Decision Processes 50, 179-211.

[18] Ruiz Mafe CR, Blas SS \& Tavera-Mesías J (2010), A comparative study of mobile messaging services acceptance to participate in television programmes. Journal of Service Management 21(1), 69102 .

[19] Ajzen I \& Fishbein M (1975), Belief, attitude, intention and behavior: An introduction to theory and research. Addison-Wesley.

[20] Davis FD, Bagozzi RB \& Warshaw PR (1989), User acceptance of computer technology: A comparison of two theoretical models. Management Science 35(8), 982-1003.

[21] Kuo YF, Wu CM \& Deng WJ (2009), The relationships among service quality, perceived value, customer satisfaction, and postpurchase intention in mobile value-added services. Computers in Human Behavior 25(4), 887-896.

[22] Liao C, Chen JL \& Yen DC (2007), Theory of planning behavior (TPB) and customer satisfaction in the continued use of e-service: An integrated model. Computers in Human Behavior 23(6), 2804 2822.

[23] Al-Azzam AFM (2015), The impact of service quality dimensions on customer satisfaction: A field study of Arab bank in Irbid city, Jordan. European Journal of Business and Management 7(15), 4553.

[24] Fong KK-Y \& Wong SKS (2015), Factors influencing the behavior intention of mobile commerce service users: An exploratory study in Hong Kong. International Journal of Business and Management 10(7), 39-47.

[25] Valtonen T, Kukkonen J, Kontkanen S, Sormunen K, Dillon P \& Sointu E (2015), The impact of authentic learning experiences with ICT on pre-service teachers' intentions to use ICT for teaching and learning. Computers and Education 81, 49-58.

[26] Utami CW (2017), Attitude, subjective norm, perceived behaviour, entrepreneurship education and self efficacy toward entrepreneurial intention university student in Indonesia. European Research Studies 10(2A), 475-495.

[27] Mahmoud MA (2014) Attitudes, subjective norms and perceived behavioural control on entrepreneurial intention of Nigerian Postgraduates in UUM. Master thesis, Universiti Utara Malaysia.

[28] Wedayanti NPAA \& Giantari IGAK (2015), Peranan pendidikan kewirausahaan dalam memediasi pengaruh norma subjektif terhadap niat berwirausaha. E-Jurnal Manajemen Unud 5(1), 533 560.

[29] Sánchez-Prieto C, Olmos-Migueláñez S \& García-Peñalvo F (2017), MLearning and pre-service teachers: An assessment of the behavioral intention using an expanded TAM model. Computers in Human Behavior 72, 644-654.

[30] Maulana HDJ, Sos S \& Kes M (2009), Promosi Kesehatan. EGC.

[31] Shin D (2014), Beyond user experience of cloud service: Implication for value sensitive approach. Telematics and Informatics 32(1), 33-44

[32] Wang H-Y \& and Wu S-Y (2014), Factors influencing behavioural intention to patronise restaurants using iPad as a menu card. Behaviour and Information Technology, 33(4), 395-409.

[33] Kalinic Z \& Marinkovic V (2016), Determinants of users' intention to adopt m-commerce: An empirical analysis. Information Systems and e-Business Management 14(2), 367-387.

[34] Moridis C, Terzis V \& Economides A (2017), The effect of instant emotions on behavioral intention to use a computer based assessment system. Proceedings of the IEEE Global Engineering Education Conference, pp. 1457-1462.

[35] Teng W, Lu H-P \& Yu H (2009), Exploring the mass adoption of third-generation (3G) mobile phones in Taiwan. Telecommunications Policy 33(10-11), 628-641.

[36] Rezaei S, Amin M, Moghaddam M \& Mohamed (2016), 3G post adoption users experience with telecommunications services: A partial least squares (PLS) path modelling approach. Nankai Business Review International 7(3), 361-394.

[37] Thirumalai S \& Sinha K (2011), Customization of the online purchase process in electronic retailing and customer satisfaction: An online field study. Journal of Operations Management 29(5), 477-487.

[38] Agag G. \& El-Masry A (2016), Understanding the determinants of hotel booking intentions and moderating role of habit. International Journal of Hospitality Management 54, 52-67.

[39] Ayeh JK (2015), Travellers' acceptance of consumer-generated media: An integrated model of technology acceptance and source credibility theories. Computers in Human Behavior 48, 173-180.

[40] Persico D, Manca S \& Pozzi F (2014), Adapting the Technology Acceptance Model to evaluate the innovative potential of e-learning systems. Computers in Human Behavior 30, 614-622.

[41] Workman M (2014), New media and the changing face of information technology use: The importance of task pursuit, social influence, and experience. Computers in Human Behavior 31, 111117

[42] Chong AY-L (2013), Understanding mobile commerce continuance intentions: An empirical analysis of Chinese consumers. Journal of Computer Information Systems 53(4), 22-30.

[43] Hao S, Dennen V \& Mei L (2017), Influential factors for mobile learning acceptance among Chinese users. Educational Technology Research and Development 65(1), 101-123.

[44] Shiau Wl \& Chau P (2016), Understanding behavioral intention to use a cloud computing classroom: A multiple model comparison approach. Information and Management 53(3), 355-365.

[45] Venkatesh V \& Davis F (2000), A theoretical extension of the technology acceptance model: Four longitudinal field studies. Management Science 46(2), 186-204.

[46] Legris P, Ingham J \& Collerette P (2003), Why do people use information technology? A critical review of the technology acceptance model. Information and Management 40(3), 191-204.

[47] Ajzen I (1985), From intentions to actions: A theory of planned behavior. In J. Kuhl \& J. Beckman (Eds.), Action Control. Berlin: Springer, pp. 11-39.

[48] Lam T \& Hsu C (2006), Predicting behavioral intention of choosing a travel destination. Tourism Management 27(4), 589599.

[49] Cheng S, Lam T \& Hsu CHC (2006), Negative word-of-mouth communication intention: An application of the theory of planned behavior. Journal of Hospitality and Tourism Research 30(1), 95116

[50] Sparks B \& Pan GW (2009), Chinese outbound tourists: Understanding their attitudes, constraints and use of information sources. Tourism Management, 30(4), 483-494.

[51] Venkatesh V, Morris MG, Davis GB \& Davis FD (2003), User acceptance of information technology: Toward a unified view. MIS Quarterly 27(3), 425-478.

[52] Alenezi AR (2011), An adoption of the TAM model to determine factors affecting students' acceptance of e-learning in institutions of higher education in Saudi Arabia. PhD thesis, Universiti Utara Malaysia.

[53] Parasuraman A, Zeithaml VA, Berry LL (1988), SERVQUAL: A multiple-item scale for measuring consumer perceptions of service quality. Journal of Retailing 64(1), 12-40.

[53] Khairi MO (2015), The moderating effects of the government support and religious obligations on the relationship between service quality, knowledge and awareness of Islamic banking system and the intention to subscribe the system in Libya. DBA thesis, Universiti Utara Malaysia.

[54] Izogo EE (2017), Customer loyalty in telecom service sector: The role of service quality and customer commitment. TQM Journal 29(1), 19-36.

[55] Aldehayyat JS, Al Khattab A \& Anchor JR (2011), The use of strategic planning tools and techniques by hotels in Jordan. Management Research Review 34(4), 477-490.

[56] Chen Y-M, Hsu TH \& Lu Y-J (2018), Impact of flow on mobile shopping intention. Journal of Retailing and Consumer Service 41, 281-287.

[57] Hur WM, Kim H \& Kim WM (2014), The moderating roles of gender and age in tablet computer adoption. Cyberpsychology, Behavior, and Social Networking 17(1), 33-39. 